\title{
FILOGENETIK KUTU PENGHISAP DARAH (Haematopinus sp.) PADA BEBERAPA JENIS SAPI BERDASARKAN GEN 18S rRNA
}

\section{Phylogenetic of Blood-Sucking Lice (Haematopinus sp.) in Some Cattles Based on 185 rRNA Gene}

\author{
Aan Awaludin ${ }^{1 *}$, Yudhi Ratna Nugraheni ${ }^{2}$, Mira Andriani ${ }^{1}$, Niswatin Hasanah ${ }^{1}$, dan Agus \\ Hadi Prayitno ${ }^{1}$ \\ 1 Jurusan Peternakan, Politeknik Negeri Jember \\ ${ }^{2}$ Fakultas Kedokteran Hewan, Universitas Gadjah Mada \\ Email: aanawaludin@polije.ac.id
}

\begin{abstract}
INTISARI
Tujuan penelitian ini adalah untuk mengetahui hubungan kekerabatan dari Haematopinus sp. yang menjadi parasit di beberapa jenis sapi yaitu sapi Simmental, Limousin, PO (Peranakan Ongole), dan FH (Friesian Holstein) dari Kabupaten Jember dan jenis sapi Simmental dan PO dari Kabupaten Karanganyar. Metode yang digunakan adalah dengan mengisolasi DNA dari sampel kutu sejumlah 6 sampel Haematopinus sp. dan diamplifikasi menggunakan universal primer $18 \mathrm{~S}$ rRNA dengan forward primer 18S (5'-TCATTACGAGGCTCTGCAAT-3') dan reverse primer 18S (5'TTCAAAGTAAACGTGTCGGC-3') yang selanjutnya dilakukan sekuensing produk PCR. Hasil sekuensing dianalisis menggunakan software MEGA 6 untuk konstruksi pohon filogenetik dengan metode Neighbor-Joining dan Maximum Parsimony. Hasil penelitian menunjukkan bahwa sampel Haematopinus sp. yang berasal dari sapi Simmental, Limousin, dan PO dari Jember, serta Simmental dan PO yang berasal dari Karanganyar adalah termasuk dalam satu cluster dengan Haematopinus quadripertusus. Sampel Haematopinus sp. dari sapi FH Jember mempunyai jarak genetik yang cukup jauh dengan Haematopinus quadripertusus yang dimungkinkan karena sekuen yang bisa dianalisis hanya $236 \mathrm{nt}$.
\end{abstract}

Kata kunci: DNA, Filogenetik, Haematopinus sp., Kutu, Sapi

\begin{abstract}
The purpose of this study was to determine the phylogenetic relationship of Haematopinus sp. which became parasites in several types of cattle, namely Simmental, Limousin, PO (Peranakan Ongole), and FH (Friesian Holstein) from Jember Regency and Simmental and PO cattle from Karanganyar Regency. The method used was to isolate DNA from 6 samples of Haematopinus sp. and amplified using $18 S$ rRNA universal primers with $18 S$ (5'-TCATTACGAGCTCTGCAAT-3) reverse primers and $18 S$ (5'-TTCAAAGTAAACGTGTCGGC-3) sequential PCR sequencing. Sequencing results were analyzed using MEGA 6 software for phylogenetic tree construction using the Neighbor-Joining and Maximum Parsimony Methods. The results showed that the sample Haematopinus sp. originating from Simmental, Limousin, and PO cattle from Jember, and Simmental and PO from Karanganyar were included in one cluster by Haematopinus quadripertusus. Haematopinus sp. sample from Jember FH cattle had a considerable genetic distance from Haematopinus quadripertusus which was possible because the sequence that could be analyzed was only $236 \mathrm{nt}$.
\end{abstract}

Keywords: DNA, Phylogenetic, Haematopinus sp., Louse, Cattle

\section{PENDAHULUAN}

Salah satu masalah utama mengenai kesehatan hewan yang berpengaruh pada peternakan di berbagai belahan dunia adalah parasit dari jenis ektoparasit (Hourigan,
1979). Kelompok kutu yang sering menjadi parasit pada sapi adalah famili Haematopin idae. Haematopinus eurysternus adalah spesies kutu yang cukup berpengaruh pada kesehatan sapi di daerah beriklim dingin, sedangkan Haematopinus quadripertusus adalah spesies 
kutu yang cukup berpengaruh pada kesehatan sapi di daerah beriklim tropis dan subtropis (Scofield et al., 2012).

Kutu merupakan parasit pada sapi yang bisa menyebabkan rasa gatal, penurunan berat badan, iritasi, rasa tidak nyaman, dan penurunan produksi air susu serta penurunan kualitas produk asal sapi (Lasisi et al., 2010). Menurut Cahyadi (2012) beberapa jenis kutu penghisap pada sapi diantaranya, yaitu Haematopinus quadripertusus, Haematopinus eurysternus, Haematopinus tuberculatus, Linognathus vituli, dan Solenopotes capillatus. Jenis-jenis kutu tersebut berparasit pada sapi dan mampu menyebabkan iritasi serta anemia sehingga produktivitas sapi akan menurun.

Haematopinus merupakan salah satu jenis parasit dari keluarga kutu yang banyak menginfeksi hewan domestik. Semua siklus hidup ektoparasit ini hanya terjadi pada induk semang dan hanya mampu bertahan hidup beberapa jam di luar tubuh induk semang (Guimaraes et al., 2001). Hadi dan Saviana (2000) menjelaskan bahwa kutu termasuk dalam ektoparasit yang bersifat obligat karena seluruh siklus hidupnya berada pada tubuh induk semangnya. Kutu yang dapat beradaptasi memiliki morfologi antara lain tidak memiliki sayap, bentuk tubuh pipih dorsoventral, sebagian besar tidak mempunyai mata, bagian mulut bertipe menusuk-isap atau untuk mengunyah, memiliki enam kaki yang kokoh dengan kuku yang besar pada ujung tarsus serta tonjolan tibia untuk merayap dan mencengkram bulu (rambut) inangnya.

Beberapa kajian molekular tentang Haematopinus sp. yang berparasit pada beberapa jenis ternak telah dilakukan. Song et al. (2014) melaporkan bahwa pada DNA mitokondria antara spesies Haematopinus sp. yang berparasit pada kuda dan babi terdapat variasi berdasarkan amplifikasi gen pada daerah 12S rDNA. Nugraheni (2015) mengidentifikasi Haematopinus sp. pada sapi potong (bangsa Limousin, Simmental, Peranakan Ongole) dan sapi perah (bangsa
Friesian Holstein) di Provinsi D.I. Yogyakarta berdasarkan morfologi dan molekular secara genotip pada daerah $18 \mathrm{~S}$ rDNA Haematopinus sp. asal 4 jenis sapi (Friesian Holstein, Limousin, Peranakan Ongole, dan Simmental) di Provinsi D.I. Yogyakarta diperoleh hasil bahwa ada kedekatan kekerabatan dengan Haematopinus quadripertusus namun berbeda spesies.

Hasil penelitian Dong et al. (2014) menunjukkan bahwa adanya variasi yang substansial dalam tingkat dan fragmentasi genom mitokondria di antara garis keturunan yang berbeda dari masing-masing jenis kutu penghisap darah pada manusia dengan kutu babi (Haematopinus suis) dan kutu babi hutan (Haematopinus apri) dengan menggunakan sekuensing genom pada mitokondria. Penelitian yang mengkaji molekular ektoparasit pada Haematopinus sp. masih jarang dilakukan di Indonesia. Oleh karena itu, penelitian ini bertujuan untuk mengkaji tentang filogenetik Haematopinus sp. pada sapi.

\section{MATERI DAN METODE}

\section{Materi Penelitian}

Penelitian ini menggunakan 6 sampel yaitu sapi Simmental, Limousin, Peranakan Ongole (PO), dan Friesian Holstein (FH) di Kabupaten Jember dan sapi Simmental, dan PO dari Kabupaten Karanganyar yang diambil secara acak. Alat yang digunakan dalam penelitian ini yaitu sarung tangan karet, pinset, dan microtube (1,5 $\mathrm{ml}$ dan $2 \mathrm{ml}$ ), beaker glass, cawan petri, GD column, mikropipet $(10 \mu \mathrm{l}, 100$ $\mu \mathrm{l}$, dan $1.000 \mu \mathrm{l})$, tip, vortex mixer, waterbath (drybath), thermalcycler, microwave, seperangkat alat elektroforesis, $U V$ transilluminator, dan kamera digital.

Bahan yang digunakan adalah etanol absolut, minyak cengkeh, etanol (50\%, 70\%, 85\%, dan 95\%), glutaraldehyde, coccodylate buffer, tannin acid, tetraoksida, tert-butanol, DNA extraction kit (Geneaid), PCR master mix (Go Taq® Green), DNA staining, agarose 
(Seakem@LE agarose), 1x buffer Tris-AcetateEDTA (TAE), loading dye, 100 bp DNA Ladder (DNA marker intron $1000 \mathrm{bp}$ ), nuclease-free water $\left(\mathrm{ddH}_{2} \mathrm{O}\right)$, dan primer pada area $18 \mathrm{~S}$ rRNA dengan forward primer $18 \mathrm{~S}$ (5'TCATTACGAGGCTCTGCAAT-3'), dan reverse primer 18S (5'-TTCAAAGTAAACGTGTCGGC3') (Nugraheni, 2015).

\section{Metode Penelitian}

Penelitian ini terdiri dari 2 tahapan yaitu pengambilan sampel dan pemeriksaan molekular. Data yang dihasilkan kemudian dianalisis dengan menggunakan konstruksi pohon filogenetik dengan metode NeighborJoining dan Maximum Parsimony.

\section{Pengambilan sampel Haematopinus sp.}

Sampel Haematopinus sp. diambil dari ujung ekor yang berambut di daerah sekitar perineum vulva, telinga, dan sekitar mata dari sapi yang terindikasi terinfeksi Haematopinus sp. dengan menggunakan pinset. Setiap satu ekor sapi diambil 5 sampai 10 ekor kutu kemudian dimasukkan dalam microtube $2 \mathrm{ml}$ berisi etanol absolut dan dihitung sebagai satu sampel kutu kemudian diberi label.

\section{Pemeriksaan molekular}

Sampel Haematopinus sp. diekstraksi menggunakan DNA extraction kit (Geneaid). Ekstraksi sampel dilakukan dengan mengambil 1 ekor kutu Haematopinus sp. yang telah difiksasi selanjutnya dicuci menggunakan akuades dan didiamkan beberapa saat kemudian dipotong dengan menggunakan blade steril. Selanjutnya dimasukkan ke dalam microtube $2 \mathrm{ml}$, ditambahkan GST $200 \mu \mathrm{l}$ dan proteinase $\mathrm{K}$ sebanyak $20 \mu \mathrm{l}$ kemudian divortex, diinkubasikan pada suhu $60^{\circ} \mathrm{C}$ selama 12 jam, disentrifus pada kecepatan 16.000 rpm selama 2 menit. Larutan supernatan dipindah ke microtube 1,5 $\mathrm{ml}$ dan ditambah GSB buffer 200 $\mu \mathrm{l}$ kemudian divortex.

Proses pengikatan DNA diawali dengan penambahan etanol absolut $200 \mu \mathrm{l}$ lalu divortek. Larutan tersebut dipindah ke column GD yang ditempatkan pada microtube $2 \mathrm{ml}$ dan disentrifus pada kecepatan 16.000 rpm selama 1 menit. Microtube $2 \mathrm{ml}$ yg berisi cairan dibuang dan column GD dipindah ke microtube $2 \mathrm{ml}$ yang baru. Pencucian DNA dilakukan dengan menambahkan $400 \mu \mathrm{l}$ W1 buffer kemudian disentrifus pada kecepatan 16.000 rpm selama 1 menit. Column GD dipindah ke microtube baru dan ditambah $600 \mu \mathrm{l}$ wash buffer, kemudian disentrifus kembali pada kecepatan 16.000 rpm selama 30 detik. Column GD dipindah pada microtube baru dan disentrifus kembali pada kecepatan 16.000 rpm selama 3 menit sehingga dihasilkan matrik column kering. Column GD ditaruh pada microtube baru kemudian ditambahkan $100 \mu \mathrm{l}$ pre heated elution buffer ke bagian tengah matrik column selama 3 menit, setelah itu dilakukan sentrifus dengan kecepatan 16.000 rpm selama 30 detik. Hasil ekstraksi DNA sampel Haematopinus sp. ini langsung digunakan untuk amplifikasi DNA atau disimpan pada suhu $-20^{\circ} \mathrm{C}$.

Hasil ekstraksi dari DNA sampel Haematopinus sp. selanjutnya dilakukan amplifikasi menggunakan primer universal $18 \mathrm{~S}$ forward primer 18S (5'TCATTACGAGGCTCTGCAAT-3') dan reverse primer 18S (5'-TTCAAAGTAAACGTGTCGGC3') (Nugraheni, 2015). Proses amplifikasi DNA pada setiap ekstraksi DNA sampel dilakukan dengan mencampur PCR master mix (Go Taq® Green) sebanyak 12,5 $\mu \mathrm{l}$ ditambah $\mathrm{ddH}_{2} 0$ (nuclease-free water) $10 \mu \mathrm{l}$ ditambah primer 1 $\mu \mathrm{l}$ forward primer 18S (5'TCATTACGAGGCTCTGCAAT-3') dan $1 \mu \mathrm{l}$ reverse primer $18 \mathrm{~S}$ (5'TTCAAAGTAAACGTGTCGGC-3') dalam microtube hingga homogen kemudian ditambah 0,5 $\mu \mathrm{l}$ ekstraksi DNA sampel sehingga didapatkan volume akhir $25 \mu$ l. Amplifikasi DNA dilakukan dengan kondisi predenaturasi $95^{\circ} \mathrm{C}$ (5 menit), denaturasi $94^{\circ} \mathrm{C}$ (1 menit), annealing $55^{\circ} \mathrm{C}$ ( 1 menit), extension $72^{\circ} \mathrm{C}$ ( 1 menit), dilakukan sebanyak 30 siklus, dan final extension $72^{\circ} \mathrm{C}$ (5 menit) dengan suhu 
akhir $4^{\circ} \mathrm{C}$. Hasil PCR DNA sampel Haematopinus sp. selanjutnya dielektroforesis pada gel agarose 2\% selama 30 menit pada 100 volt.

Pembuatan gel agarose 2\% dengan melarutkan agarose (Seakem@LE agarose) sebanyak 0,50 g ke dalam $25 \mathrm{ml} 1 \mathrm{x}$ buffer TrisAcetate-EDTA (TAE) yang dididihkan di dalam erlenmeyer $100 \mathrm{ml}$ menggunakan microwave. Larutan agarose didinginkan selama 10 menit dan ditambahkan 2,5 $\mu \mathrm{l}$ DNA staining diaduk sampai homogen, kemudian dituang secara perlahan ke dalam cetakan dan kemudian dipasang sisir pencetak sumuran. Selanjutnya gel agarose dibiarkan mengeras kemudian sisir pencetak diangkat. Gel agarose diletakkan ke dalam unit elektroforesis berisi $1 \mathrm{x}$ buffer Tris-Acetate-EDTA (TAE).

Hasil dari PCR DNA sampel Haematopinus sp. masing-masing diambil sebanyak $5 \mu \mathrm{l}$ kemudian dicampur dengan $2 \mu \mathrm{l}$ loading dye $\mathrm{di}$ atas parafilm kemudian dimasukkan ke dalam sumuran. Sumur pertama diisi dengan campuran $3 \mu$ sebagai penanda molekuler (marker) $100 \mathrm{bp}$ dan $2 \mu \mathrm{l}$ loading dye. Hasil gel elektroforesis divisualisasikan dengan menggunakan $U V$ transiluminator dan didokumentasikan dengan kamera digital. Proses sekuensing DNA dilakukan di Balai Uji Standar Karantina Ikan, Pengendalian Mutu, dan Keamanan Hasil Perikanan (BUSKIPMKHP) Jakarta.

\section{Analisis data}

Hasil dari uji molekular (sekuensing DNA) dianalisis menggunakan software MEGA 6 untuk mendapatkan konstruksi pohon filogenetik (Tamura et al., 2013) dengan metode Neighbor-Joining dan Maximum Parsimony (Tamura et al., 2011).

\section{HASIL DAN PEMBAHASAN}

Sampel Haematopinus sp. ditemukan pada ujung ekor yang berambut, sekitar telinga, dan sekitar perineum vulva terutama bagian bawah dari sapi yang terinfeksi Haematopinus sp. (Gambar 1).

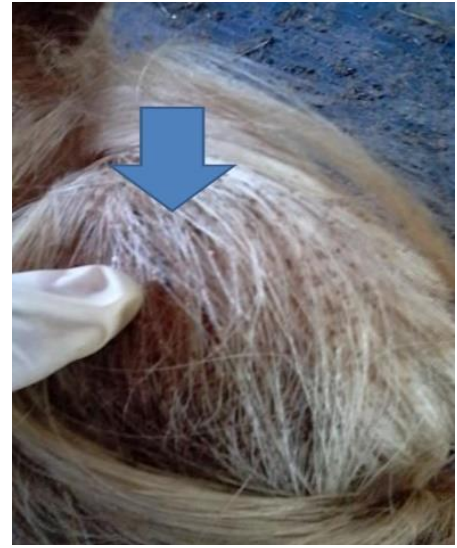

Gambar 1. Infestasi Haematopinus sp. pada ujung ekor.

Haematopinus sp. yang dikoleksi merupakan spesies dari Haematopinus quadripertusus. Menurut Scofield et al. (2012) bahwa Haematopinus quadripertusus adalah spesies kutu yang cukup berpengaruh pada kesehatan sapi di daerah beriklim tropis dan subtropis.

DNA dari sampel Haematopinus sp. berhasil diisolasi dan diamplifikasi dengan terlihatnya band yang jelas pada 910 bp dengan menggunakan universal primer pada area 18S rRNA (Gambar 2). Menurut Meyer et al. (2010) sub unit kecil gen 18S rRNA adalah salah satu area yang sering digunakan dalam studi filogenetik.

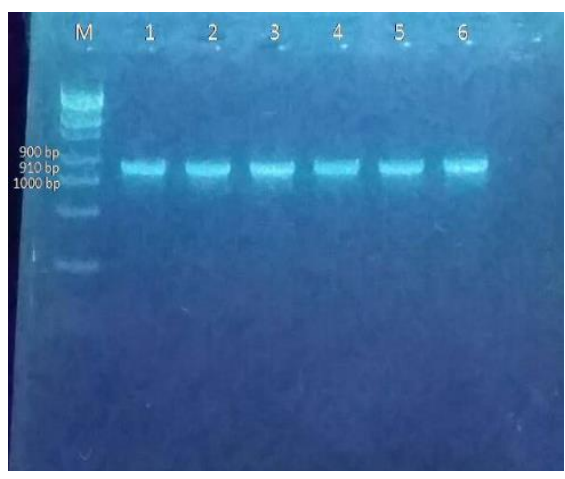

Gambar 3. Hasil amplifikasi DNA region $18 \mathrm{~S}$ rRNA (910 bp) sampel kutu.

Keterangan M. Marker:

1. Haematopinus sp. dari sapi FH Jember;

2. Haematopinus sp. dari sapi Simmental Jember;

3. Haematopinus sp. dari sapi Limousin Jember; 
4. Haematopinus sp. dari sapi PO Jember;

5. Haematopinus sp. dari sapi Simmental Karanganyar;

6. Haematopinus sp. dari sapi PO Karanganyar.

Penghitungan jarak genetik dilakukan dengan menggunakan metode Kimura-2Parameter yang tersaji pada Tabel 1. Jarak genetik sampel Haematopinus sp. dihitung dengan pembanding dari GenBank yang terdiri dari spesies Haematopinus quadripertusus (GenBank: KJ522491.1) dan pembanding outgroup dari spesies Linognathus africanus (GenBank: LT598598.1).

Hasil analisis data jarak genetik didapatkan hasil $0 \%$ dari sampel Haematopinus sp. dari sapi Simmental Jember, Limousin Jember, PO Jember, Simental Karanganyar, dan PO Karanganyar dengan Haematopinus quadripertusus (GenBank: KJ522491.1) sehingga sangat dimungkinkan sampel Haematopinus sp. tersebut adalah spesies Haematopinus quadripertusus.

Hasil yang berbeda didapatkan pada analisis sampel Haematopinus sp. dari sapi FH Jember yang mempunyai jarak genetik 6\% dengan Haematopinus quadripertusus (GenBank: KJ522491.1), namun hal tersebut belum bisa untuk menyimpulkan bahwa sampel Haematopinus sp. dari sapi FH Jember sebagai spesies baru walaupun perbedaan $2 \%$ sudah merupakan spesies yang berbeda. Hal tersebut dikarenakan dari primer target 910 bp nukleotida pada sekuensing region $18 \mathrm{~S}$ rRNA dari Haematopinus sp. (GenBank: JQ309927.1) sebanyak 2.835 bp didapatkan hasil yang teranalisis hanya 236 nt sehingga hasil sekuensing yang teranalisis belum bisa mewakili untuk identifikasi pada penentuan spesies baru secara akurat.

Meskipun demikian, hasil analisis tersebut masih bisa digunakan untuk melakukan deteksi kedekatan kekerabatan. Menurut Nugraheni (2015) Haematopinus sp. yang teridentifikasi sebagai spesies Haematopinus quadripertusus dari sapi
Simmental, Limousin, FH, dan PO di Provinsi D.I. Yogyakarta memiliki jarak genetik $0 \%$ dengan Haematopinus quadripertusus (GenBank).

Tabel 1. Jarak Genetik (Metode Kimura-2Parameter).

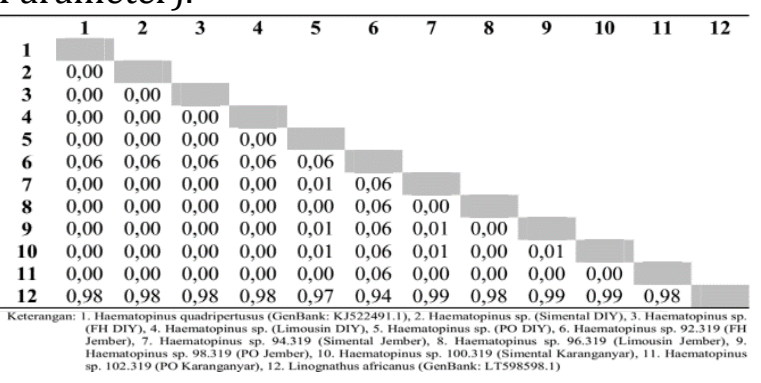

Hasil analisis pohon filogenetik dengan menggunakan konstruksi Neighbor-Joining dengan bootstrap 1.000x menunjukkan bahwa semua sampel Haematopinus sp. masih dalam satu cabang dengan Haematopinus quadripertusus (GenBank) dengan nilai validitas 98\%. Sampel Haematopinus sp. dari sapi FH Jember walaupun masih dalam satu cabang, namun memiliki jarak genetik yang lebih jauh dengan Haematopinus quadripertusus (GenBank) (Gambar 3).

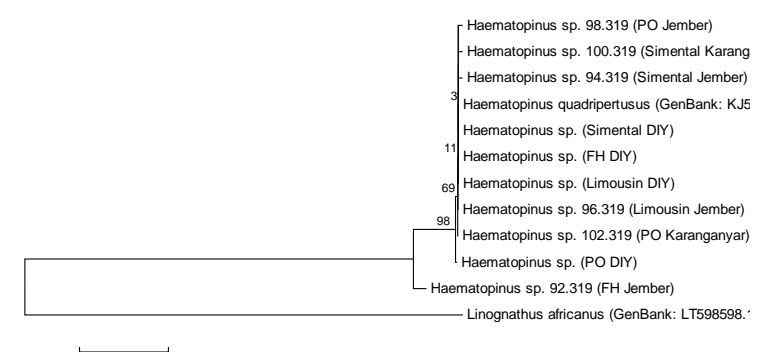

Gambar 3. Konstruksi pohon filogenetik Neighbor-Joining dengan bootstrap 1000x.

Hasil analisis pohon filogenetik dengan menggunakan konstruksi Maximum Parsimony dengan bootstrap 1.000x menunjukkan hasil kemiripan dengan Haematopinus quadripertusus (GenBank) dengan validitas rendah. Haematopinus sp. asal sapi FH Jember erat hubungannya dengan Linognathus africanus dengan validitas $100 \%$ mungkin karena sekuen yang teranalisis hanya $236 \mathrm{nt}$ atau tidak termasuk Haematopinus sp. secara molekuler (Gambar 4). 


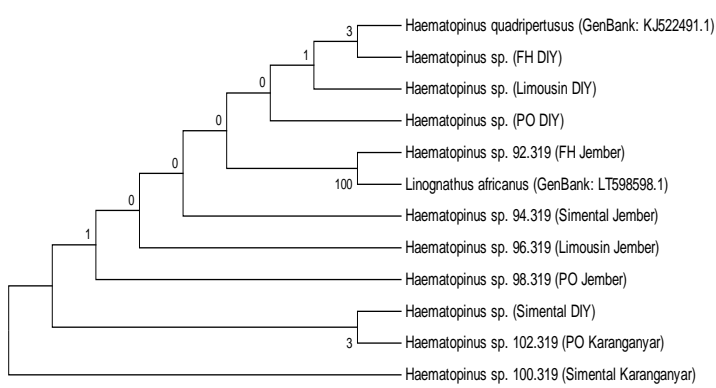

Gambar 4. Konstruksi pohon filogenetik Maximum Parsimony dengan bootstrap $1.000 \mathrm{x}$

Hasil pemeriksaan molekular yang meliputi analisis jarak genetik (Kimura-2Parameter) konstruksi pohon filogenetik Neighbor-Joining dan Maximum Parsimony pada sampel Haematopinus sp. sapi Simmental Jember, Limousin Jember, PO Jember, Simmental Karanganyar, dan PO Karanganyar menunjukkan sebagai spesies Haematopinus quadripertusus dengan nilai validitas beragam, sedangkan pada sampel kutu sapi FH Jember dimungkinkan bukan spesies Haematopinus quadripertusus.

\section{KESIMPULAN}

Sampel Haematopinus sp. yang berasal dari sapi Simmental, Limousin, dan PO dari Jember, serta Simmental dan PO yang berasal dari Karanganyar adalah termasuk dalam satu cluster dengan Haematopinus quadripertusus. Sampel Haematopinus sp. dari sapi FH Jember mempunyai jarak genetik yang cukup jauh dengan Haematopinus quadripertusus yang dimungkinkan karena sekuen yang bisa dianalisis hanya $236 \mathrm{nt}$.

\section{DAFTAR PUSTAKA}

Cahyadi. 2012. Infeksi Kutu Pada Hewan (Anjing, Kucing, Sapi, Kuda, Domba, Kambing, Ayam, Kalkun, Merpati dan Itik).

http://cahyadiblogsan.blogspot.com/20 12/06/infeksi-kutu-pada-hewananjing-kucing.html. Diakses 6 April 2016.
Dong, W., S. Song, D.C. Jin, X. Guo, and R. Shao. 2014. Fragmented mitochondrial genomes of the rat lice, polyplax asiatica and polyplax spinulosa: intra-genus variation in fragmentation pattern and a possible link between the extent of fragmentation and the length of life cycle. BMC Genomic. 15(44).

Guimaraes, J.H., E.C. Tucc, and D.M. BarrosBattesti. 2001. Ectoparasitos de Importância Veterinária. Plêiade, São Paulo.

Hadi, U.K. dan S. Saviana. 2000. Ektoparasit: Pengenalan, Diagnosis dan Pengendaliannya. Fakultas Kedokteran Hewan. Institut Pertanian Bogor. Bogor.

Hourigan, J.L. 1979. Spread and detection of Psoroptic scabies of cattle in the United States. Journal of American Veterinary Association. 175:1278-1280.

Lasisi, O.T., Eyarefe, and J.O. Adejinmi. 2010. Anaemia and mortality in calves caused by the short-nosed sucking louse (Haematopinus eurysternus) (Nitzsch) in Ibadan. Nigerian Veterinary Journal. 31(4):295-299.

Meyer, A., C. Todt, N.T. Mikkelsen, and B. Lieb. 2010. Fast evolving 18S rRNA sequences from Solenogastres (Mollusca) resist standard PCR amplification and give new insights into mollusk substitution rate heterogeneity. BMC Evolutionary Biology. 10(70):1-12.

Nugraheni, Y.R. 2015. Identifikasi Morfologi dan Molekuler Kutu Haematopinus sp. pada Sapi Lokal dan Impor Yogyakarta. Tesis. Fakultas Kedokteran Hewan. Universitas Gadjah Mada. Yogyakarta.

Scofield, A., K.F., Campos, A.M., Melo da Silva, C.H.S. Oliveira, J.D. Barbosa, and G. GoesCavalcante. 2012. Infestation by Haematopinus quadripertusus on cattle in São Domingos do Capim, state of Pará. Revista Brasileira de Parasitologia Veterinaria. 21(3):315-318.

Song, S.D., S.C. Barker, and R. Shao. 2014. Variation in mitochondrial minichromosome composition between blood sucking lice of the genus Haematopinus that infest horses and pigs. Parasit Vectors. 7:7-144.

Tamura, K., D. Peterson, N. Peterson, G. Stecher, M. Nei, and S. Kumar. 2011. MEGA5: molecular evolutionary 
genetics analysis using maximum likelihood, evolutionary distance, and maximum parsimony methods. Molecular Biology Evolution. (28): 27312739.

Tamura, K., G. Stecher, D. Peterson, A. Filipski, and S. Kumar. 2013. MEGA6: molecular evolutionary genetics analysis version 6.0. Molecular Biology Evolution. 30(12):2725-2729. 